DOI: $10.21448 / \mathrm{ijsm} .416258$

\title{
Cold Resistance of Plant Species of the Genus Vitex I. Introduced in M.M. GRYSHKO National Botanic Garden of NAS of Ukraine
}

\author{
Nataliia Levchyk (iD*1, Volodymyr Levon (D)2
}

\author{
${ }^{1}$ Department of cultivated flora M.M. Gryshko National Botanical Gardens, National Academy of Science of \\ Ukraine, Kyiv, Ukraine \\ ${ }^{2}$ Department of fruit plants acclimatization M.M. Gryshko National Botanical Gardens, National Academy of \\ Science of Ukraine, Kyiv, Ukraine
}

\begin{abstract}
Results of current studies of flavonoids content in vegetative and reproductive organs and their dynamics under cold stress in plants of the genus Vitex L. introduced in the M.M. Gryshko National Botanic Garden (NBG) of NAS of Ukraine are summarized. The varying effects of flavonoids on different plant organs during adaptation to different climatic and weather conditions of introduction are analyzed. The relation of dynamics of these compounds and the pigment level, photosynthetic rate, breath, transpiration, morphological and anatomical specifics of stomata is observed.
\end{abstract}

\section{ARTICLE HISTORY}

Received: 15 January 2018

Revised: 20 February 2018

Accepted: 28 April 2018

\section{KEYWORDS}

Vitex species, flavonoids, cold stress, vegetative and reproductive organs, physiological processes, pigments.

\section{INTRODUCTION}

Since ancient times, people were surrounded by plants known for their nutritional, medical and decorative properties. If such plants were absent in the local flora, the seeds, planting materials or plants were taken far away and introduced locally. At all times, the botanical gardens were engaged in enriching regional floras with new and exotic species.

Conserving and enhancing plant species diversity and varieties with introduced species are still relevant; the introduced plants have complex valuable economic and biological properties, which define their diverse use. Of many medical and odoriferous plants, species of the genus Vitex L. are prospective for introduction under the conditions of the forest-steppe zone of Right-Bank Ukraine. These plants are characterized by valuable medicinal, nutritional, aromatic, melliferous, technical and decorative properties, and can be used for different purposes in pharmaceutical industry, cosmetology, food and landscape construction, particularly.

CONTACT: Nataliia Levchyk $\square$ levchyk.n@ukr.net $\equiv$ Department of cultivated flora M.M. Gryshko National Botanical Gardens, National Academy of Science of Ukraine, Kyiv, Ukraine 
Taxonomically, the genus Vitex L. belongs to Magnoliophyta or Angiospermae, class Rosopsida, order Lamiales, suborder Lamiineae, family Verbenaceae, and subfamily Viticoideae [1].

More than 250 species (or more than 380, according to various sources [2]) are included in the genus. They are common in the Caucasus, Central Asia and Asia Minor, Mediterranean, North America, Northwest Africa, and New Zealand. In Ukraine, these plants grow in Crimea and in 1960s they were cultivated in the south of Ukraine and in Transcarpathia [3-6].

Vitex plants were brought to the American continent from Europe and the East. Today they are widely grown and naturalized there, from Maryland, the District of Columbia and New York to the states of Florida, Missouri, Arkansas, Texas and New Mexico [6].

Plants of the genus Vitex are widespread in tropical and subtropical regions in nature. They prefer wet areas near the banks of streams and rivers (especially near river mouths, in the ditches and valleys), coastal and seaside areas, sandy and dried-up alluvial soils, rocky areas near the sea, as well as limestone slopes, sunny and hot areas and grooves [7].

Plants of three Vitex species, which are part of collection of aromatic plants of the M.M. Gryshko National Botanic Garden of NAS of Ukraine, belong to the group of scientific objects which represent national treasure of our country. Species and varieties of plants of the genus Vitex are the important source for creating varieties with high promise for selection, which will enrich the biodiversity of the cultivated flora of Ukraine.

Plants of the studied Vitex species are bushes up to $2.9 \mathrm{~m}$ high with the upright stems covered with silky glandulosous in the conditions of introduction. Plant stems are usually perennial, but in adverse hibernation conditions they can freeze to the root cervix or to the level of snow cover. In spring the shoot system is restored by the sleeping buds (Fig. 1).

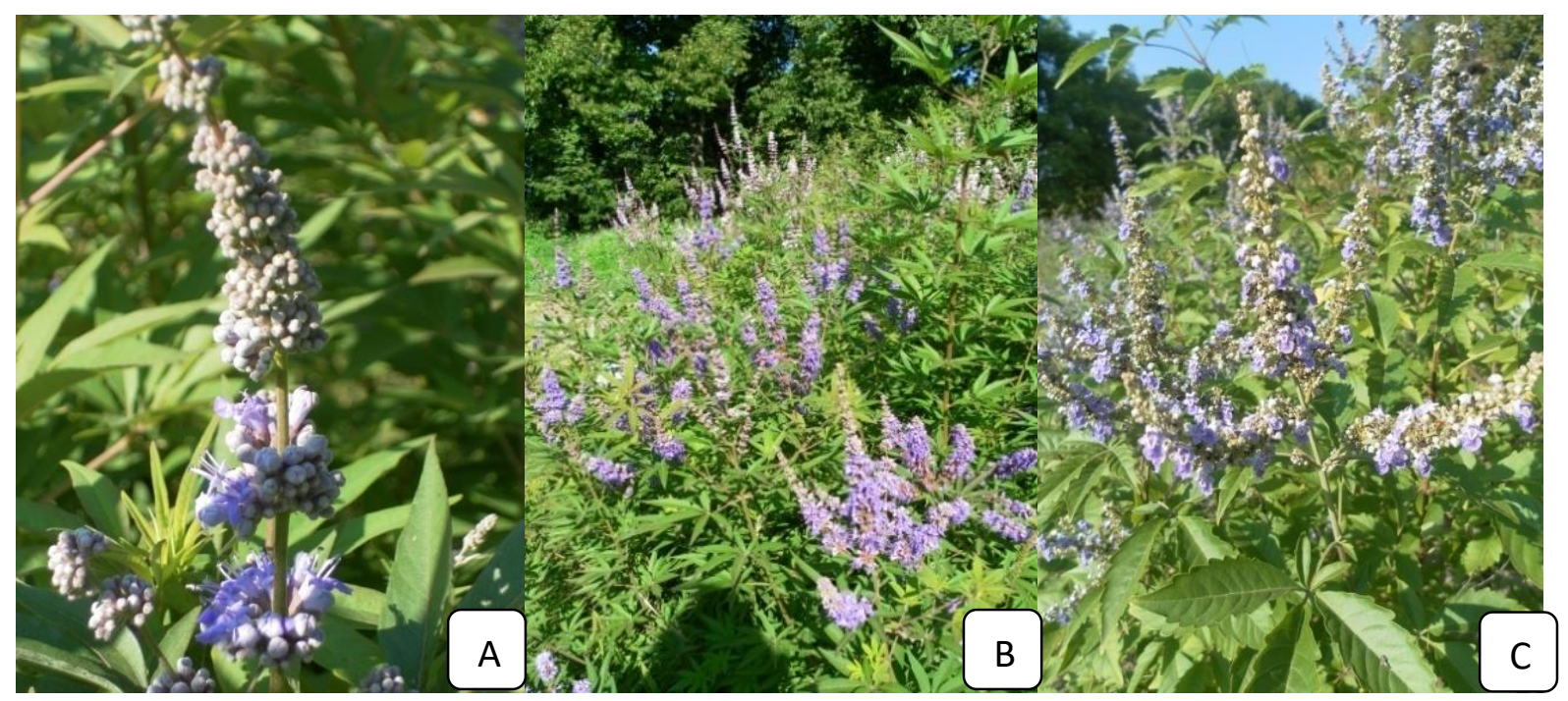

Fig. 1. Plants of species of the genus Vitex L. from the M.M. Gryshko NBG collection: A - V. agnuscastus; B - V. cannabifolia; $\mathrm{C}-V$. negundo.

It has been established that species of the genus Vitex are plants with the late start and late end of vegetation period in the conditions of introduction. The beginning of plant growth is observed in the III decade of April - the II decade of May with the sum of active air temperatures above $+10^{\circ} \mathrm{C}-120-190^{\circ} \mathrm{C}$ and the average air temperature $+16-22.5^{\circ} \mathrm{C}$ daily. The 
duration of vegetation for the forest-steppe of Right-Bank Ukraine is $167 \pm 15.10$ days for $V$. agnus-castus, $169.3 \pm 18.88$ for $V$. cannabifolia and $170.7 \pm 18.56$ days for $V$. negundo [8].

The flower cluster of Vitex plants is thyrsus. The plants have floral reversion and start blooming in III decade of June to the II decade of July when the sums of active temperatures are $525-900^{\circ} \mathrm{C}$. Blooms last for $67-77$ days in $V$. agnus-castus, $110-115$ days in $V$. cannabifoliata and 91-115 days in V. negundo [8].

The flower of Vitex plants is complete, hermaphrodite, xenogamous, symmetrical, irregular, tetracyclic with a double perianth formed with calyx and sertulum different in appearance and colors, and dichlamydeous. Flower formula for the studied Vitex species is $\uparrow \mathrm{Ca}_{(5)} \mathrm{Co}_{(2+3)} \mathrm{A}_{2,2} \mathrm{G}_{(2)}$. The flower cumulosol is 5-bladed or 5-dentate, and remains on fruit. The surface is ribbed with a webbing of veins, densely covered with glandular and nonglandular hairs. The sertulum is symmetrical, zygomorphic, sympetalous, separated into the sympetalous cylindrical tube, the 5-bladed slanting curvature (the immature part) and the point of transition from tube to bend, the throat. The lower dorsal sepal is the three-bladed, large (the typical landing place for pollinators in all Lamiales) with wavy edge and a ring of hairs; the upper dorsal sepal raised over it, formed by accreted curves of two petals.

By morphology of pollen grains, the species can be divided into plants with pollen with erratic, netted surface and numerical perforation (V. agnus-castus and $V$. cannabifolia) and plants with smooth and netted surface of pollen with a large number of small openings $(V$. negundo). The largest pollen grains $(35.6 \times 19.5$ microns $)$ are found in $V$. agnus-castus, the smallest $(30.3 \times 16.1$ microns $)$ has $V$. negundo [8].

The fruit is small stinging, spherical, dry four-nested stone fruit with the lignified endocarp [9], from 3 to $4 \mathrm{~mm}$ in diameter [3-5, 10] breaking into four monospermous nut-like mericarps. The fruits ripen in late summer and fall [11]. There are good harvests of seeds almost annually. Typically, there are four nut-like mericarps per fruit in V. agnus-castus, and fewer (two or three) in $V$. cannabifolia and $V$. negundo due to the reduction of dissepiments and seed embryos.

The blooming phase and end of vegetation are the optimum periods for accumulation of secondary metabolites in plants [12].

The largest quantities of essential oil (0.24-0.65\%) are found in the V. agnus-castus plants, $V$. cannabifolia produces almost as much (0.06-0.31\%), the smallest amount is typical for $V$. negundo (0.04-0.13\%). The maximum content of essential oils is typical for blossoming, fructification and end of vegetation periods. The blend composition of essential oil is one of species-specific characters of plants of the genus Vitex. 1.8-cineole, sabinene, citrene and $\alpha-$ pinene are typical for $V$. agnus-castus, $\beta$-caryophyllene, sabinene, caryophyllene oxide are typical for $V$. cannabifolia and $V$. negundo [8].

The plants of the studied species during the adaptation and acclimatization developed certain frost resistance, sufficient to survive the frosts of -25 to $-30^{\circ} \mathrm{C}$. The shoot tissues are damaged significantly by the frosts over $-30^{\circ} \mathrm{C}$, causing freezing to the root crown or to the level of a snow cover. The plants of $V$. cannabifolia have the best frost resistance abilities, $V$. negundo have the worst, and the plants of V. agnus-castus are in between [13].

Aim: climate changes, extreme weather conditions and environmental disasters affect the plants, changing their resistance and species ranges. Besides, introduction has an environmental impact on plant organisms, which remains a relevant and unresolved problem. The aim of our research was to elucidate the mechanism of formation of resistance to cold, low positive temperatures and weak frosts, to identify an adaptive component formed under cold stress, to discover the level of resistance to stress of the studied Vitex plants for preservation of the diversity, successful cultivation and optimum usage of plant raw materials. 


\section{MATERIALS AND METHODS}

Plants of the introduced species of the genus Vitex from the collection of aromatic plants of department of cultural flora of M.M. Gryshko NBS of NAS of Ukraine (Vitex agnus-castus, $V$. cannabifolia, $V$. negundo) were studied. The content of flavonoids expressed as rutine was defined according to V.Yu. Andreyeva and G.I. Kalinina [14] in modification of V.F. Levon [12]. Samples of two grams of dry leaves were taken for laboratory analyses. The photosynthetic rate, the intensity of photorespiration, transpiration and dark respiration were studied according to A.T. Mokronosov [15]. The content of chlorophylls and carotenoids pigments was measured according to M.M. Musiyenko [16]. The measurement of stomata cells of species of the genus Vitex took place in the AxioVision program.

\section{RESULTS AND DISCUSSION}

The mechanism of formation of plant resistance to new climate conditions is necessarily connected with morphological and biochemical, physiological and molecular changes. The ability to resist both abiotic and biotic factors of the environment is the general prerequisite for the survival of a plant. Low temperatures and temporary freezing are some of the important abiotic stresses that cause damage to plants, reduce their immunity and cause yield loss in important crops.

When the plant prepares to and withstands stress, its levels of expression of different coldresponsive genes oscillate, specific protective compounds (proteins, amino acids, sugars and polyamines) are accumulated, the composition of the membrane changes, the activity of antioxidant systems increases, metabolic and physiological processes are reorganized, and it synthesizes a number of biologically active compounds to overcome cold [17].

Flavonoids are a group of biologically active compounds of polyphenolic origin with the general formula C6-C3-C6, accumulated in all plant organs as glycosides. Flavonoids are some of the main nutrients responsible for resistance to adverse conditions and protection of plants from various harmful environmental influences. Biotic and abiotic stress can lead to the intensification of biosynthesis of flavonoids in different anatomical parts of a plant [18].

Over 300 of flavons, flavonols and isoflavonoids from different plants are known today. Flavonoids are divided into catechins, anthocyans, chalcones, flavanones, flavones, flavanols according to the oxidation level of the pyran fragment [19]. Flavonoids are found in all plant parts, but are distributed unevenly. They are active metabolites of a plant cell, accordingly to localization in a plant. There are more flavonoids in actively functioning organs like flowers, fruits (color and aroma), leaves, sprouts, and in surface tissues with protective functions. The flavonoids content is lower in shoots, and the least is in the root system [20].

Flavonoids are the main pigments in flower. In leaves they block ultra-violet radiation which is destructive for nucleic acids and proteins, and usually selectively absorb blue-green and red light, important for photosynthesis [21]. Flavonoids are also in buds, pollen of flowers, trunk cortex, in wood and in plant secretions [22]. There is insufficient data on flavonoids in seeds [20]. Different organs and tissues of plants can be different not only by quantitative, but also by qualitative content of flavonoids [18].

There are plenty of data on biosynthesis of flavonoids. The biosynthesis of flavonoids in plants happens in three steps: formation of the main part (polyketide and shikimate pathways), further development of different C6-C3-C6 flavonoids, and the final modification by hydroxylation, methylation, glycosidation causing the differentiation of flavonoids in each class. The chalcones are essential for biosynthesis of flavonoids of different classes [20, 2325]. 
Numerous studies have shown that the biosynthesis of flavonoid backbones, and their modifications are influenced by a variety of internal and external factors. It is revealed, firstly, that the multi-stage process of flavonoid formation in plants is regulated by a complex enzyme system. Secondly, the genetic factor plays an important role in the regulation of biosynthesis of flavonoids. Along with the internal factors important for the biosynthesis and regulation of flavonoids, the environmental factors also have the influence. Light, higher and lower temperature, humidity, chemical composition of soil, extreme conditions of the environment have the strongest influence on the biosynthesis of flavonoids among the external factors. Consequently, the set of external factors of the environment and conditions of growth definitely affect the biosynthesis of flavonoids [20, 22, 26].

Oxidation of flavonoids occurs during the ripening of seeds. Oxidation results in polymeric compounds in the surface seed cover, which leads to darkening of the coatings and reduction of water permeability [27, 28]. During the oxidative transformation of flavonoids, intracellular oxygen and water are used to prevent germination and spoilage of seeds [27, 29]. The flavonoids of seed coating, namely proanthocyanins, are important for preserving the seeds during storage. The presence of these compounds in the seed shell ensures the resistance to mechanical damage, water stress, pathogenic microorganisms, and pests [18]. This fact is extremely important since it enables the selection and creation of new plant varieties with extended storage period. In addition, according to modern studies, flavonoids in nontransparent impenetrable seed shells can protect them against UV-light, providing the opportunity to transport seeds in space [30].

The biological function of flavonoids should be mentioned. Due to the chemical basis, flavonoids take part in the oxidoreduction processes of the plant. Many flavonoid compounds have the antioxidant properties [20,25]. The chelating compounds can be formed with different metals and flavonoids [31, 32]. Polysaccharides binding indicate their involvement in carbohydrate metabolism, proteins binding indicate their participation in the formation of some enzymes that take an active part in many biochemical processes. The presence of flavonoids in chloroplasts explains their participation in photophosphorylation and other biochemical processes in chloroplasts [20].

Flavonoids are also considered as signals increasing the sensitivity of plant roots to mycorrhiza and inducing the start of symbiosis with tuberous bacteria and mycorrhizal fungi [18].

Flavonoids are important in plant immune responses. Due to phytoncide properties, they are involved in the formation of plant resistance to diseases, fungal and especially bacterial infections. Phenolic compounds are essential for the healing of mechanical damage and regeneration of plants, as well as for the protection of cells from the radiation, free radicals, mutagens, oxidants. In addition, flavonoids can absorb the shortwave light, turning it into longer wavelengths. In combination with anthocyanins they regulate the distribution of light energy absorbed by the leaf, without participation in photosynthesis on a direct basis [33].

Phenolic compounds are instrumental in utilizing excessive active oxygen formed in photosynthesis [27]. Any abiotic stress causes the overproduction of $\mathrm{H}_{2} \mathrm{O}_{2}$ in chloroplasts, mitochondria and peroxisome plant cell together with the release of peroxidase and catalase from these organs. A significant amount of $\mathrm{H}_{2} \mathrm{O}_{2}$ diffuses into the vacuole as the main site of accumulation of flavonoids able to neutralize $\mathrm{H}_{2} \mathrm{O}_{2}$ and other reactive forms of oxygen [18].

A lot is known about the impact of flavonoids as activators of IAA oxidase on the growth and development of plants, during IAA biosynthesis or as its nonspecific inhibitors. Consequently, flavonoids are not just by-products of metabolism, they are essential in many life processes of plants [33]. In addition, the content of flavonoids depends on and can indicate 
the level of environmental pollution [34]. In general, the main function of flavonoids as secondary metabolites is ecological in the broad sense. These are biochemical means by which the rooted-in plant solves its ecological problems of survival throughout its existence [35].

In our previous research we have found that the quantitative content of flavonoids of the studied Vitex plants is influenced by a complex of factors related to the metabolism processes. It is reliant on the internal rhythm of plant development and water exchange during the vegetation period. In spring, summer and fall months, there are two periods while the flavonoid content in leaves is maximum, during budding and at the end of vegetation. It was found that plants of $V$. agnus-castus and V. cannabifolia species tend to accumulate more flavonoids than $V$. negundo plants. It is species-specific irrespective of plant's age [8].

Let us review the flavonoid content dynamics in the plants of the genus Vitex at the end of the growing season under stress caused by the first frosts. Before the frost, the highest level of flavonoids was $1.132 \mathrm{mg} / \mathrm{g}$ in $V$. agnus-castus, the medium level of $0.885 \mathrm{mg} / \mathrm{g}$ in $V$. negundo, and the lowest, $0.783 \mathrm{mg} / \mathrm{g}$, in $V$. cannabifolia. After the first frosts, the level of flavonoids in $V$. agnus-castus decreased, in $V$. negundo it remained stable and in V. cannabifolia it slightly increased. After more frosts, the level of flavonoids decreased to $0.949 \mathrm{mg} / \mathrm{g}$ in $V$. agnus-castus, remained stable in $V$. negundo and slightly increased to $0.906 \mathrm{mg} / \mathrm{g}$ in $V$. cannabifolia (Fig. 2).

The freezing of water in the intercellular ducts and cells, accompanied by dehydration, osmotic shock, mechanical injury of the membranes cause the damage and death of hibernating plants [36]. Cold damage is accompanied by destructive processes, namely loss of turgor, chlorophyll decomposition, protein hydrolysis, decreased photosynthesis and respiration, which cause the damage of ultra structure of chloroplasts and mitochondria [37]. Reduced sensitivity of plants to frost indicates complex chemical processes in cells, the development of cryoprotective systems that can mitigate the effect of low temperatures on plant by minimizing the probability of ice formation inside cells, maintaining supercooled liquid water, reducing the freezing temperature for cellular solutions and ice formation in the intercellular space and lowering the cellular dehydration through loss of water and ice crystals in the intercellular ducts [37].

From the experimental data, it is evident that plants of $V$. cannabifolia had an increased content of flavonoids during the first and second frosts (Fig. 2). This can be explained by the fact that flavonoids are osmotically active low molecular weight substances that form hydrophilic colloids, retain water, protect plant proteins and act as cryoprotectants for the studied plants. The appropriate response of the plant is to accumulate flavonoids due to cold stress, resulting in greater stability and ensuring the survival of that plant and its whole species. 


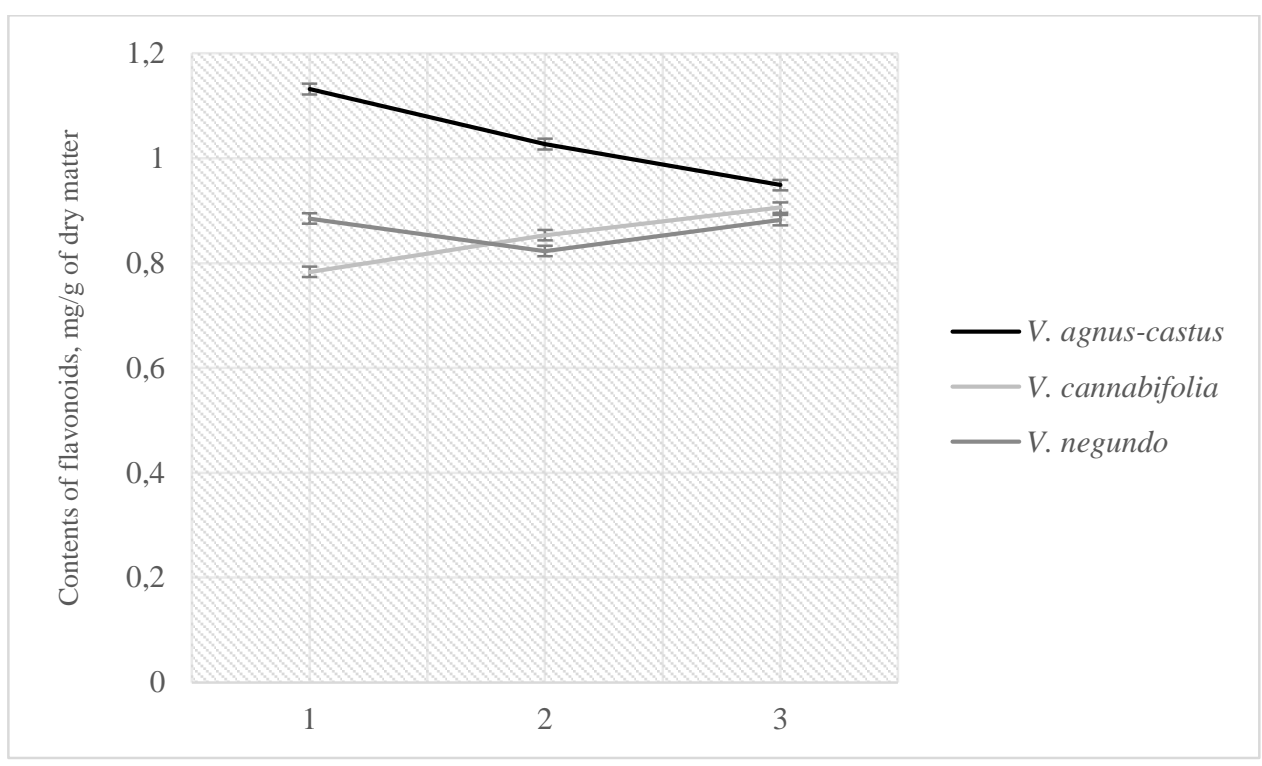

Fig. 2. Dynamics of accumulation of flavonoids during the frosts in leaves of Vitex plants: 1 - before the frosts, 2 - after the first frosts, 3 - after the second frosts

Plants of V. agnus-castus type had the highest level of flavonoids in leaves at the beginning of the experiment, but lost a lot of them during the frost period. Thus, they lost cryoprotectors and the possibility to resist cold stress. In contrast, V. negundo plants did not loose a significant amount of flavonoids due to the first frosts and restored their level after the second frosts.

According to the dynamics of the flavonoids content in the species $V$. cannabifolia and $V$. negundo, the plants reacted adequately to cold stress and their adaptability to the conditions of introduction is higher. The reaction of $V$. agnus-castus was opposite: its flavonoids were consumed without later restoring the level necessary for water retention and colloidal state of cells to ensure survival.

It is important to note that the plants obtained a certain level of frost resistance, sufficient to withstand the frost of $-25^{\circ} \mathrm{C}$ during acclimatization, according to our previous studies [13]. The highest frost resistance was found in V. cannabifolia plants, the average in V.agnus-castus, and $V$. negundo plants were the most vulnerable to frost.

According to L.G. Kosulina [38], different organs of thermophilic cultures have different resistance to cold. The content of flavonoids in vegetative and reproductive organs of Vitex plants varies from 0.729 up to $0.949 \mathrm{mg} / \mathrm{g}$, regardless of species and organ (Fig. 3).

It is essential that flavonoids are adaptive in fruits or seeds during the rest periods. In particular, seeds of plants of the genus Vitex, as is typical for plants of temperate and subtropical climate, belong to type of seeds with deep exogenous physiological rest $\left(\mathrm{V}_{3}\right)$. It is caused by a strong physiological inhibition of germination mechanism and manifests in reduced gas permeability of seed surface and special physiological condition of the embryo. Organic or physiological rest delays the germination of seeds even when all the conditions are favorable, and is connected with properties of seeds or fruits [39].

The oxidized flavonoids in the dry, leathery and ligneous pericarp of the studied Vitex species perform protective function, controlling gas and water intake of fruit, and providing physiological rest for seeds allowing embryos to ripe. The highest level of flavonoids, 0.893 $\mathrm{mg} / \mathrm{g}$ are in fruits of $V$. cannabifolia, average level, $0.802 \mathrm{mg} / \mathrm{g}$ in $V$. negundo, and the lowest level, $0.729 \mathrm{mg} / \mathrm{g}$ is in V. agnus-castus (Fig. 3). 


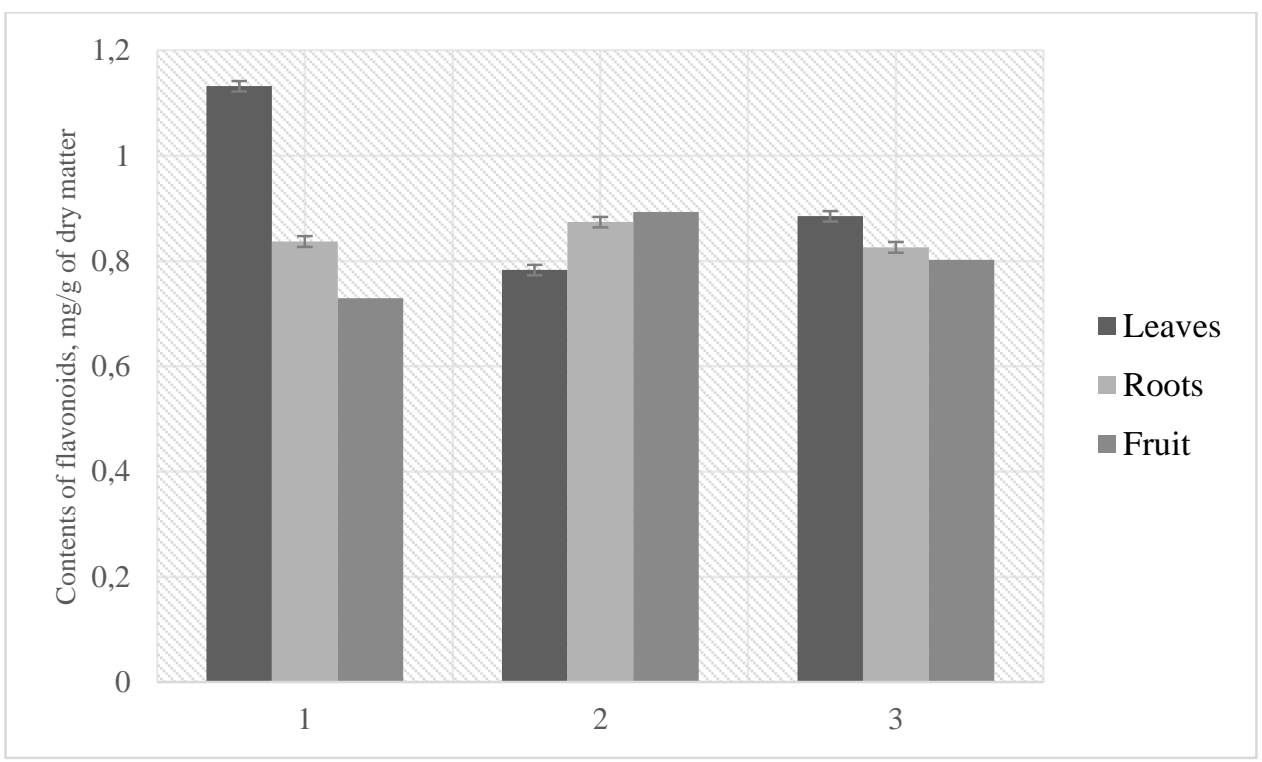

Fig. 3. Content of flavonoids in vegetative and reproductive organs in plants of the genus Vitex L.: 1 V. agnus-castus, 2 - V. cannabifolia, 3 - V. negundo.

Besides, our conclusions are similar with the results obtained by D. Tepfer (2012) and I.D. Anikeeva (1990) in influential space research of the mechanism in seeds counteracting the effects of interplanetary space and the role of flavonoids of seed membranes in this process. They found that flavonoids protect sunflower and flax seeds from UV irradiation, temperature fluctuations, and even vacuum conditions during the transportation of seeds to Mars. The chemical samples of flavonoid UV screens were destroyed by UV light, but their overall ability to absorb UV was retained. Even if it would be impossible to store seeds, the components (e.g., DNA) could remain viable during transportation in space [30, 40].

The tendency to accumulate the highest level of flavonoids in leaves, average in roots and minimum in fruits is revealed for species of $V$. agnus-castus and $V$. negundo. The tendencies for the maximum accumulation of flavonoids in fruits, average in roots and minimum in leaves (Fig. 3) are characteristic of $V$. cannabifolia. Obviously, the importance of these compounds differs for different plant organs. They ensure reproduction success and survival in fruits and seeds, surviving as a separate individual in roots, and protective situational reaction for the fast restoration of leaves.

Along with flavonoids, the photosynthetic rate and transpiration are the defining physiological adaptations which influence stamina, general productivity and cropping capacity. Respiration is important for adaptation processes of plants as a source of power. The low temperatures cause the reduction of oxygen intake rate and inhibit respiration in heat-loving plants [38].

The highest indicators of photosynthesis with the minimum level of transpiration were obtained in $V$. negundo plants $\left(14.3 \mathrm{mg}\right.$ of $\left.\mathrm{CO}_{2} /\left(\mathrm{dm}^{2} \times \mathrm{h}\right)\right)$, the average level $(13.0 \mathrm{mg}$ of $\mathrm{CO}_{2} /\left(\mathrm{dm}^{2} \times \mathrm{h}\right)$ ) was typical for $V$. cannabifolia and the lowest level of gas exchange functions (7.3 $\mathrm{mg}$ of $\mathrm{CO}_{2} /\left(\mathrm{dm}^{2} \times \mathrm{h}\right)$ ) for $V$. agnus-castus (Table 1$)$. 
Table 1. The comparative characteristic of gas exchange processes for plants of the genus Vitex L.

\begin{tabular}{|c|c|c|c|c|}
\hline \multirow{2}{*}{$\begin{array}{l}\text { Species of the } \\
\text { genus Vitex }\end{array}$} & Photosynthesis & Photorespiration & Dark respiration & \multirow{2}{*}{$\begin{array}{c}\text { Transpiration } \\
\mathrm{mg} \text { of } \mathrm{H}_{2} \mathrm{O} /\left(\mathrm{dm}^{2} \times \mathrm{h}\right)\end{array}$} \\
\hline & \multicolumn{3}{|c|}{$\mathrm{mg}$ of $\mathrm{CO}_{2} /\left(\mathrm{dm}^{2} \times \mathrm{h}\right)$} & \\
\hline V. negundo & 14.3 & 4.1 & 2.3 & 1.25 \\
\hline V. cannabifolia & 13.0 & 2.1 & 1.3 & 2.13 \\
\hline V. agnus-castus & 7.3 & 2.9 & 1.7 & 2.33 \\
\hline
\end{tabular}

It is obvious that the plants are more thermoresistant with higher levels of photosynthesis, and their physiological processes are faster, more proficient and productive. The processes of photosynthesis, photorespiration and transpiration in Vitex plants are interconnected, interrelated and vary depending on the size, density and status of stomata cells (Table 2).

Table 2. Size and density of stomata of leaf areas of plants of the genus Vitex L. (per unit surface of leaf area)

\begin{tabular}{lcccccc}
\hline & \multicolumn{2}{c}{ Vitex agnus-castus } & Vitex cannabifolia & \multicolumn{2}{c}{ Vitex negundo } \\
\hline $\begin{array}{l}\text { Quantity of stomata, } \\
\text { units } / \mathrm{mm}^{2}\end{array}$ & \multicolumn{2}{c}{$103.6 \pm 0.50$} & \multicolumn{2}{c}{$156.1 \pm 0.33$} & $275.2 \pm 0.45$ \\
\hline $\begin{array}{l}\text { Size of stomata, } \\
\text { microns }\end{array}$ & length & width & length & width & length & width \\
\cline { 2 - 7 } & $16.24 \pm 0.45$ & $12.40 \pm 0.31$ & $20.19 \pm 0.75$ & $15.18 \pm 0.51$ & $19.57 \pm 0.78$ & $13.50 \pm 0.96$ \\
\hline
\end{tabular}

In addition, the gas exchange parameters in $V$. negundo plants (with the average size of stomata densely located on the leaf surface) are characterized by a minimum transpiration level (1.25 $\mathrm{g}$ of $\mathrm{H}_{2} \mathrm{O} /\left(\mathrm{dm}^{2} \times \mathrm{h}\right)$ ) with the maximum indicators of photosynthesis $(14.3 \mathrm{mg}$ of $\left.\mathrm{CO}_{2} /\left(\mathrm{dm}^{2} \times \mathrm{h}\right)\right)$, photorespiration $\left(4.1 \mathrm{mg}\right.$ of $\left.\mathrm{CO}_{2} /\left(\mathrm{dm}^{2} \times \mathrm{h}\right)\right)$ and dark respiration $(2.3 \mathrm{~g}$ of $\left.\mathrm{H}_{2} \mathrm{O} /\left(\mathrm{dm}^{2} \times \mathrm{h}\right)\right)$. Thus, it can be assumed that the physiological processes in plants of this species are the most balanced for the conditions of forest-steppe of Right-Bank Ukraine.

Plants of $V$. cannabifolia (with the largest stomata and average density of stomata) have

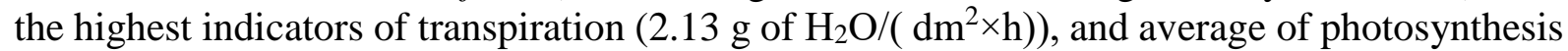
$\left(13.0 \mathrm{mg}\right.$ of $\left.\mathrm{CO}_{2} /\left(\mathrm{dm}^{2} \times \mathrm{h}\right)\right)$ and photorespiration $\left(2.1 \mathrm{mg}\right.$ of $\left.\mathrm{CO}_{2} /\left(\mathrm{dm}^{2} \times \mathrm{h}\right)\right)$. Thus, the balance of processes and fitness of those plants in introduction is average.

Plants of V. agnus-castus (the smallest stomata and low density of stomata) lose the largest amount of water due to transpiration $\left(2.33 \mathrm{~g}\right.$ of $\left.\mathrm{H}_{2} \mathrm{O} /\left(\mathrm{dm}^{2} \times \mathrm{h}\right)\right)$, need constant replenishment, have the lowest intensity of photosynthesis $\left(7.3 \mathrm{~g} \mathrm{of} \mathrm{H}_{2} \mathrm{O} /\left(\mathrm{dm}^{2} \times \mathrm{h}\right)\right)$ and dark respiration $\left(1.7 \mathrm{~g}\right.$ of $\left.\mathrm{H}_{2} \mathrm{O} /\left(\mathrm{dm}^{2} \times \mathrm{h}\right)\right)$. Thus, the plants of this species are the most sensitive and vulnerable in forest-steppe condition of the Right-Bank Ukraine.

The status of the pigment system and the plastid apparatus is a significant indicator of the plant resistance to unfavorable environmental conditions, and in particular to the cold, because the pigments are closely related to proteins and lipids [38]. Low temperatures destruct the plastid structure, which leads to the inhibition of photosynthesis. The ratio of chlorophyll $a$ to chlorophyll $b$ characterizes the relationships between plant and environment. It is important to note that the increase of chlorophyll content $b$ is a sign of stress that requires a lot of energy and leads to a certain depletion of the plant. In addition, a high level of correlation of chlorophyll content with the content of carotenoids also indicates the presence of stress (Table 3).

Our previous studies have shown that the pigment content in plants of the genus Vitex (regardless of their species and age) is dynamic throughout the vegetation season (Table 3). The 
maximum content of chlorophyll $a$ and carotenoids was observed at the beginning of the vegetation, in the phase of regrowth and budding, the minimum content was in the flowering phase; the chlorophyll $b$ content was maximum in the flowering phase. After the flowering phase until the end of the growing season, there is a tendency for all species for gradually decrease the content of all pigments.

The high amount of pigments in leaves of investigated Vitex plants in the first half of their vegetation directly correlates with intensive plant growth, high productivity of photosynthesis, and preparation for flowering. We agree with N.I. Yakushkina [41] and E.R. Hyubbenet [42] that the increased chlorophyll level can be used as an indicator of the plant's readiness for flowering.

During mass blossoming of plants of the genus Vitex the ratio of pigments changed: levels of chlorophyll $a$ and carotenoids sharply decreased, chlorophyll $b$ content increased twice or thrice, and was considerably prevalent over two other pigments. The increase of chlorophyll $b$ content is the sign of stress conditions, and the blossoming is a stressful stage in the life of a plant. The energy expenses are greater and exhaust the plant to an extent. Plants of $V$. negundo species had the highest level of chlorophyll $b$ in the flowering stage $(0.98 \mathrm{mg} / \mathrm{g}), \mathrm{V}$. cannabifolia was characterized by the average level $(0.83 \mathrm{mg} / \mathrm{g})$, and the lowest level $(0.78 \mathrm{mg} / \mathrm{g})$ was found in V. agnus-castus plants.

The high ratio of chlorophylls to carotenoids contents also highlights the plant stress. During blossoming, such indicators of this ratio were recorded: the highest $(39.25 \mathrm{mg} / \mathrm{g})$ for the $V$. negundo, average $(20.85 \mathrm{mg} / \mathrm{g})$ for $V$. agnus-castus and the lowest $(19.00 \mathrm{mg} / \mathrm{g})$ for $V$. cannabifolia.

The carotenoids are important for the reproductive process of plants, thus their content is minimum in leaves during blossoming. At the same time, according to references, the quantity of these pigments considerably increases in anthers and petals of plants [41].

By their reaction to temperature conditions, plants of the genus Vitex belong into the second group of moderately thermophilic plants that can be damaged by not severe, short-term frosts $\left(0\right.$ to $\left.-3^{\circ} \mathrm{C}\right)$ but will not perish, and without considerable damages can survive the decrease of temperature below $+5^{\circ} \mathrm{C}$. Such short-term decreases of temperature are entirely possible in the regions of their origin and growth.

Hence, thermophilic plants of the genus Vitex can withstand the specified temperature range. This possibility manifests itself in qualitative content of pigments and their ratio and in general content of chlorophyll, intensity of gas exchange processes, dynamic content of flavonoids, functional status of plants and is developed under the influence of not a single one, but a system of factors. 
Table 3. The content of photosynthetic pigments in leaves of plants of the genus Vitex L. according to vegetative stages (dry substance, $\mathrm{mg} / \mathrm{g}$ )

\begin{tabular}{|c|c|c|c|c|c|c|c|c|c|c|}
\hline $\begin{array}{l}\text { Species of } \\
\text { the genus } \\
\text { Vitex }\end{array}$ & Pigments & $\begin{array}{l}\text { Regrowth and } \\
\text { budding }\end{array}$ & Blossoming & Fructification & $\begin{array}{c}\text { End of } \\
\text { vegetation }\end{array}$ & Ratio & Regrowth & Blossoming & Fructification & $\begin{array}{c}\text { End of } \\
\text { vegetation }\end{array}$ \\
\hline \multirow{3}{*}{$\begin{array}{l}\text { V.agnus- } \\
\text { castus }\end{array}$} & Chlorophyll $a$ & $1.80 \pm 0.03$ & $0.47 \pm 0.01$ & $0.98 \pm 0.02$ & $0.71 \pm 0.01$ & $a / b$ & 5.81 & 0.60 & 6.53 & 5.07 \\
\hline & Chlorophyll $b$ & $0.31 \pm 0.002$ & $0.78 \pm 0.02$ & $0.15 \pm 0.004$ & $0.14 \pm 0.004$ & $a+b$ & 2.11 & 1.25 & 1.13 & 0.85 \\
\hline & Carotenoids & $1.22 \pm 0.03$ & $0.06 \pm 0.002$ & $0.59 \pm 0.005$ & $0.53 \pm 0.01$ & $a+b /$ carot & 1.73 & 20.83 & 1.92 & 1.60 \\
\hline \multirow{3}{*}{$\begin{array}{l}\text { V.cannabifoli } \\
a\end{array}$} & Chlorophyll $a$ & $1.86 \pm 0.01$ & $0.50 \pm 0.01$ & $1.10 \pm 0.01$ & $0.37 \pm 0.002$ & $a / b$ & 5.03 & 0.60 & 5.24 & 5.29 \\
\hline & Chlorophyll $b$ & $0.37 \pm 0.001$ & $0.83 \pm 0.02$ & $0.21 \pm 0.006$ & $0.07 \pm 0.002$ & $a+b$ & 2.23 & 1.33 & 1.31 & 0.44 \\
\hline & Carotenoids & $1.30 \pm 0.03$ & $0.07 \pm 0.001$ & $0.61 \pm 0.005$ & $0.34 \pm 0.002$ & $a+b /$ carot & 1.72 & 19.0 & 2.15 & 1.29 \\
\hline \multirow{3}{*}{ V.negundo } & Chlorophyll $a$ & $2.10 \pm 0.07$ & $0.59 \pm 0.02$ & $0.91 \pm 0.06$ & $0.55 \pm 0.01$ & $a / b$ & 3.82 & 0.60 & 5.69 & 4.23 \\
\hline & Chlorophyll $b$ & $0.55 \pm 0.01$ & $0.98 \pm 0.03$ & $0.16 \pm 0.01$ & $0.13 \pm 0.003$ & $a+b$ & 2.65 & 1.57 & 1.07 & 0.68 \\
\hline & Carotenoids & $1.25 \pm 0.09$ & $0.04 \pm 0.006$ & $0.52 \pm 0.03$ & $0.40 \pm 0.01$ & $a+b / c a r o t$ & 2.12 & 39.25 & 2.06 & 1.70 \\
\hline
\end{tabular}




\section{CONCLUSION}

Plants of three species of the genus Vitex L. were studied. The plants were acclimatized in forest-steppe conditions of Right-Bank Ukraine as perspective introduced species with valuable medicinal, nutritional, aromatic, melliferous, technical and decorative properties that can be used in many segments of the industry of Ukraine, mostly in pharmaceutics, cosmetology, food processing and landscape construction. As a result:

- in the conditions of introduction, different strategies of resisting cold stress in plants were revealed: increasing the levels of cryoprotectors (such as flavonoids) in vegetative and reproductive organs in $V$. cannabifolia, maintaining their contents at certain stable level in $V$. negundo, or losing them in $V$. agnus-castus. Therefore, the content of flavonoids and their dynamics can be considered indicative of stressful condition in plants of the genus Vitex and their adaptive ability during the introduction;

- the highest level of flavonoids in fruits $(0.893 \mathrm{mg} / \mathrm{g})$ was in plants of $V$. cannabifolia, the average level $(0.802 \mathrm{mg} / \mathrm{g})$ in $V$. negundo plants, and the lowest $(0.729 \mathrm{mg} / \mathrm{g})$ in $V$. agnuscastus plants. This provides deep physiological stillness for seeds and possibility of reproduction of plants in new climate conditions;

- the most tolerant to cold are the plants of $V$. negundo, followed by plants of $V$. cannabifolia, and the least tolerant to low temperatures are the plants of $V$. agnus-castus due to the intensity of photosynthetic rate, transpiration and respiration processes which are directly connected with the size and density of stomata on a leaf surface and the content of pigments.

Orcid

Nataliia Levchyk (D) https://orcid.org/0000-0001-8668-8763

Volodymyr Levon (D) https://orcid.org/0000-0003-2652-9984

\section{REFERENCES}

[1]. Takhtajan A. (2009). Flovering plants (Second Edition) - Springlerscience+Business Media V.P., $871 \mathrm{p}$.

[2]. Hoberg E. (1999). Phytochemical and analytical investigations of Vitex agnus-castus L. Diss. Institute of technology Zurich № 13285, Zurich, 127 p.

[3]. Нечитайло В.А. (2005). Ботаніка. Вищі рослини, К.:Фітосоичіочентр, 432 с.

[4]. Прокудин Ю.Н., Доброчаева Д.Н, Котов М.И. (1987). Определитель высших растений Украины, Киев: Наукова думка, 548 с.

[5]. Flora Europaea edited by T.G. Tutin, V.H. Heywood. (1972). Cambridge at the university press, Volume 3 Diapensiaceae to myoporaceae, P. 122.

[6]. Illustrated flora of the Northeastern United States and Adjacent Canada by Henry A. Gleason, Ph.D. (1963). New York and London: Hafner publishing company, INC., Vol. 3 The sympetalous dicotyledoneae, P. 138-139.

[7]. Фуфарек Ф. (1982). Растительный мир Земли: Пер. с нем. / Москва: Мир, Т.2, 184 с.

[8]. Левчик Н.Я., Рахметов Д.Б. (2015) Види роду Vitex L. в Лісостепу України: інтродукція, біологія і використання, Київ: Фітосоиіочентр, 246 с.

[9]. Abbas Azimi R., Jamzad Z., Sefidkon F. and Bakhshi-Khaniki Gh. (2006). The potential value of phytochemical and micromorpgological characters in taxonomic treatment of genusVitex L. (Lamiaceae), Iran.Journ.Bot.,12(1), P.15-35.

[10]. Moldenke HN. (1968). Additional notes on the genus Vitex, 7. Phytologia 16(6), P. 487502.

[11]. Zasada John C. (2008). Vitex agnus-castus lilacchastetree, The Woody Plant Seed Manual, handbook on seeds and shrubs, [Electronic resource], access mode: http://www.nsl.fs.fed.us. 
Int. J. Sec. Metabolite, Vol. 5, No. 2, (2018) pp. 149-155

[12]. Левчик Н.Я. (2014). Динамика накопления флавоноидов и дубильных веществ в надземной биомассе представителей рода Vitex L. на протяжении вегетации, Москва: Проблемы агрохимии и экологии, №3, С. 46-51.

[13]. Левчик Н.Я., Макарова Д.Г., Китаєв О.І. (2014). Морозостійкість рослин видів роду Vitex L. в умовах інтродукції в Національний ботанічний сад ім. М.М. Гришка НАН України, Інтродукція рослин, № 4(64), С. 12-21.

[14]. Андреева В.Ю., Калинкина Г.И. (2000). Разработка методики количественного определения флавоноидов в манжетке обыкновенной Alhcemilla vulgaris L.S.L., Химия растительного сырья, №1, С. 85-88.

[15]. Мокроносов А.Т. (1989). Фотосинтез и биопродуктивность: методы определения, Москва: Агропромиздат, 460 с.

[16]. Мусієнко М.М., Паршикова Т.В., Славний П.С. (2001). Спектрофотометричні методи в практиці фізіології, біохімії та екології рослин, Київ: Фітосоціоцентр, 200 c.

[17]. Єфіменко Т.С., Антонюк М. 3. (2014). Молекулярні механізми стійкості рослин до низьких температур, Наукові записки НаУКМА. Біологія та екологія, Том 158, С. 3 13.

[18]. Макаренко О.А., Левицкий А.П. (2013). Физиологические функции флавоноидов в растениях, Физиология и биохимия культ. растений, Т. 45, №2, С. 100-112.

[19]. Тараховский Ю.С., Ким Ю.А., Абдрасилов Б.С., Музафаров Е.Н. (2013). Флавоноиды: биохимия, биофизика, медицина, Пущчино, Synchrobook, 310 c.

[20]. Новрузов Э.Н. (2010). Пигменты репродуктивных органов растений и их значение, Баку: «Эльм», 312 с.

[21]. Рейвн П., Эверт Р., Айкхорн С. (1990). Современная ботаника: в 2-х т., Москва: Мир, T.2, $344 \mathrm{c}$.

[22]. Машковская С.П., Дзюба О.И. (2002). Флавоноиды интродуцированных видов Tagetes L. и их аллопатическая активность, Физиол. и биохим. культур.раст., T. 54, №6, С. 517-523.

[23]. Запрометов М.Н. (1971). Фенольные соединения и их биологические функции, Москва: Наука, 185 с.

[24]. Харборн Дж. (1968). Биохимия фенольных соединений, Москва: Мир, 451 с.

[25]. Harborne J., Mabry T., Mabry H. (1975). The flavonoids. London:, 1204 p.

[26]. Масляников П.В., Чупахина Г.Н. (2001). Влияние монохроматического света на біосинтез антоцианов, Теор. и прикл. аспекты экологии и биохимии. Калининград: Калининград. Унив., С. 48-52.

[27]. Червяковский Е.М., Курченко В.П., Костюк В.А. (2009). Роль флавоноидов в биологических реакциях с переносом электронов, Белорус. Гос.ун-m, 19 с.

[28]. Egley G.H. [et al.] (1985). Peroxidase involvement un lignifications in water-impermeable seed coats of weedyleguminous and malvaceous species, Plant, Cell \& Environ., Vol. 8, №4, P. 253-260.

[29]. Bailly, C. (2004). Active oxygen species and antioxidants in seed biology, SeedSci. Res., Vol. 14, № 2, P. 93-107.

[30]. David Tepfer, Andreja Zalar, Sydney Leach. (2012). Survival of Plant Seeds, Their UV Screens, and nptIIDNA for 18 Months Outside the International Space Station, Astrobiology, Volume 12, Number 5, May, P. 517-528.

[31]. Fedenko V., Shemet S., Struzhko V. (2005). Complexation of cyaniding with cadmium ions in solution, Ukr. Biochim. Zh., V. 77, №1, P. 104-109.

[32]. Hix L., Lockwood S., Bertram J. (2004). Bioactive carotenoids: potent antioxidants and regulators of gene expression, Redox. Rep., V.9, №4, P. 181-191. 
[33]. Гродзинский А.М. (1973). Краткий справочник по физиологии растений, Киев: Наук. думка, 591с.

[34]. Новза Ю.А., Попова Е.М., Вініченко О.В. (2015). Флавоноїди у листі каштану кінського Aesculus hippocastanum L. як показник екологічного навантаження, Проблеми екологічної біотехнології, № 2, С. 83-92.

[35]. Архипова Н.С., Елагина Д.С. (2017). Изучение особенностей накопления биологически активных веществ некоторыми дикорастущими травянистыми растениями, Научно-практ.журнал «Овощи России», №2 (35), С. 86-91.

[36]. Мусієнко М.М. (2001). Фізіологія рослин: Підручник, Київ: Фітосоиіочентр, 392 с.

[37]. Гродзинский Д.М. (2013). Адаптивная стратегия физиологических процессов растений, Киев: Наук. думка, 302 с.

[38]. Косулина Л.Г., Луценко Э.К., Аксенова, В.А. (2011). Физиология устойчивости растений к неблагоприятным факторам среды, Ростов Н/Д: Изд-во Рост. ун-та, $236 \mathrm{c}$.

[39]. Николаева М.Г., Разумова М.В., Гладкова В.Н. (1985). Справочник по проращиванию покоящихся семян, Ленинград: Наука, 347 с.

[40]. Anikeeva, I.D., Akatov, Y.A., Vaulina, E.N., Kostina, L.N., Marenny, A.M., Portman, A.I., Rusin, S.V., and Benton, E.V. (1990). Radiobiological experiments with plant seeds aboard the biosatellite Kosmos 1887. Int J Rad ApplInstrum D 17:167-171.

[41]. Якушкина Н.И., Бахтенко Е.Ю. (2004). Физиология растений, Москва: Гуманит. Изд. Центр Владос, 463 с.

[42]. Гюббенет Е.Р. (1951). Растение и хлорофилл, Москва/Ленинград.: Изд-во АН СССР, C. $159-184$. 